\title{
Sleep disorders and quality of life of harvesters rural labourers
}

\author{
Joseane Lima', Sueli Rossini², Rubens Reimão³
}

\begin{abstract}
The various kinds of work may interfere in the laborer's quality of sleep. Among the factors, the unemployment caused by the period between the coffee harvests on the agriculture of South Minas may influence the appearance of anxiety and depression symptoms, and it may cause impairments to the quality of life and changes in the rural laborers' pattern of sleep. Objective: To appraise the sleep and the effects on the quality of life in the rural laborers in the period between the coffee harvests. Method: In the study-group, 40 patients, rural laborers, were evaluated, and in the control-group, 40 patients, fixed laborers. Instruments used: clinical interview, The Pittsburgh Sleep Quality, Index Beck Anxiety Inventory, Hamilton Depression Rating Scale, and World Health Organization Quality of Life. Results: The study-group showed impairment in the quality of the sleep; anxiety and depression signals and symptoms were high in both groups; being them higher in the harvesters laborers; the quality of life presented good levels in both groups, with losses in the domain "social relationship" between the harvesters; the sleep disturbances influenced the appearance of anxiety and depression signs and symptoms, but they did not interfere in the perception of the quality of life. Conclusion: The rural laborers that have fixed labors are less exposed to the symptoms of anxiety and depression - along with sleep disorders - than the harvesters laborers. Thus, the study-group's perception of the quality of life is better than the control-group's.
\end{abstract}

Key words: sleep disorders, unemployment, quality of life, anxiety, rural labor.

\section{Distúrbios do sono e qualidade de vida de trabalhadores rurais safristas}

\section{RESUMO}

As diversas formas de trabalho podem interferir na qualidade do sono do trabalhador. Entre os fatores, o desemprego ocasionado pela entressafra da cultura cafeeira nas lavouras sul mineiras pode influenciar no surgimento de sintomas de ansiedade e de depressão e causar prejuízos na qualidade de vida e alterações no padrão do sono dos trabalhadores rurais. Objetivo: Avaliar o sono e as repercussões na qualidade de vida em trabalhadores rurais na entressafra cafeeira. Método: No grupo-estudo foram avaliados 40 pacientes trabalhadores rurais e no grupo-controle 40 pacientes trabalhadores fixos. Instrumentos utilizados: entrevista clínica, The Pittsburgh Sleep Quality Index, Beck anxiety Inventory, Hamilton depression rating Scale e World Health Organization Quality of Life. Resultados: O grupo-estudo apresentou prejuízo na qualidade do sono; sinais e sintomas de ansiedade e depressão foram elevados nos dois grupos, sendo maior nos trabalhadores safristas; a qualidade de vida apresentou bons níveis nos dois grupos, havendo perdas no domínio "relações sociais" entre os safristas; os distúrbios do sono influenciaram no surgimento de sinais e sintomas de ansiedade e depressão, mas não interferiram na percepção da qualidade de vida. Conclusão: Trabalhadores rurais detentores de trabalho fixo estão menos expostos aos sintomas de ansiedade e depressão - acompanhados de distúrbios do sono - que os trabalhadores safristas. Assim, a percepção da qualidade de vida do grupoestudo é melhor que a do grupo-controle.

Correspondence
Rubens Reimão

Rua dos Bogarís 38

04047-020 São Paulo SP - Brasil

E-mail: reimaorubensneuro@yahoo.com

Received 23 September 2009

Received in final form 21 December 2009

Accepted 5 January 2010
Palavras-chave: distúrbios do sono, desemprego, qualidade de vida, ansiedade, trabalho rural.

Sleep Medicine Advanced Research Group, Division of Clinical Neurology, Clinical Hospital, University of São Paulo School of Medicine, São Paulo SP, Brazil: 'Psychologist; ${ }^{2}$ Psychologist, PhD; ${ }^{3}$ Neurologist, MD, PhD. 
In search of a quality of life, we observe the increasing of researches that investigate the depression, anxiety, and sleep ${ }^{1}$. They are disturbances that may compromise the development of the individual, and even disqualify him/her for labor.

The labor, which is responsible for the support and for the guarantee of survival, is also essential for the maintenance of the man's quality of life ${ }^{2}$.

This study is a product of the observation of the medical and psychological search for assistance in a health assistance center of a city of the coffee region of Minas Gerais, with increase in the period between the coffee harvests and marked decrease with the beginning of the harvest. Harvester rural laborers that complained about bad sleep, anguishes and sorrows followed by pains formed most of the patients, during the period between the harvests. These laborers suffer from the insecurity of the unemployment for a long period of time, what may compromise the support and the quality of their lives and of their families ${ }^{3,4}$.

The objective of the present study was to evaluate the pattern and the quality of the sleep, the quality of life, the anxiety and depression symptoms levels in a sample of harvester rural laborers that seek for assistance in a health center.

\section{METHOD}

During the period between the harvests, 40 harvester rural laborers were evaluated ( 33 females and 7 males), selected for the psychological and medical assistance in a health unity, and invited to take part in the study. In the control-group, 40 fixed rural laborers ( 9 females and 31 males) signed up in the basic health network and in the city's health unity, were evaluated. All the subjects signed the free and informed consent term. The research was started after the approval of the Ethics Committee for the Analyses of Research Projects - CAPPesq from the Clinical Direction of the Clinical Hospital, University of São Paulo Medical School (n 748/05).
The questionnaires used were applied individually due to possible difficulties in reading, because of the patients' low level of learning.

At first, the patients were evaluated with the Mini Exam of the Mental Health (MEEM) $)^{5}$ to exclude those ones who did not score 20 . Two of the patients did not get the minimal score and were excluded from the research. The semi-conducted interview was used to know about the marital status, the level of school, the working link and the occupation during the period between the coffee harvests. The following instruments were used: The Pittsburgh Sleep Quality Index (PSQI) ${ }^{6}$ to quantify the quality of the sleep, in which scores above five indicate a bad quality of sleep; Beck Anxiety Inventory $(\mathrm{BAI})^{7}$ with the intention of evaluating the anxiety symptoms; Hamilton Scale for Depression Evaluation (HAM-D) ${ }^{8}$, to investigate the symptoms and attitudes connected to the temper, suicidal ideals, insomnia, work and another signs of depression; and moreover, World Health of Quality of Life in its brief version (WHOQOL - bref) $)^{9}$ to evaluate the perception of the quality of life.

The statistical treatment was performed through the descriptive analyses (frequencies, average and standard deviations) to compare the average age among the groups with the impaired t-Student test; from the chi-squared test in the gender comparison. Agresti's homogeneity chi-squared tests were performed to check the existence of association among the laborers group and the sleep scale, anxiety symptoms, depression symptoms when distinguished in graduations ${ }^{10}$. Mann-Whitney's non-parametric test was used in the score comparison of quality of life among the groups. To verify the correlation between the scales and the harvest time, the Spearman's correlations were used.

\section{RESULTS}

In Table 1, we can observe significant difference in relation to the gender, with the number of females $(82.5 \%)$ being statistically superior to the one in the study-group

Table 1. Control and study group's gender, level of school and social status.

\begin{tabular}{|c|c|c|c|c|c|c|c|c|}
\hline \multirow[b]{3}{*}{ Variable } & \multirow[b]{3}{*}{ Category } & \multicolumn{4}{|c|}{ Group } & & & \multirow[b]{3}{*}{$p$} \\
\hline & & \multicolumn{2}{|c|}{ Study } & \multicolumn{2}{|c|}{ Control } & \multicolumn{2}{|c|}{ Total } & \\
\hline & & $\mathrm{n}$ & $\%$ & $\mathrm{n}$ & $\%$ & $\mathrm{n}$ & $\%$ & \\
\hline \multirow[t]{2}{*}{ Gender } & $\mathrm{F}$ & 33 & 82.5 & 9 & 22.5 & 42 & 52.5 & \multirow{2}{*}{$<0.001$} \\
\hline & M & 7 & 17.5 & 31 & 77.5 & 38 & 47.5 & \\
\hline \multirow[t]{2}{*}{ School level } & Elem. school & 36 & 90.0 & 40 & 100 & 76 & 95.0 & \multirow{2}{*}{$0.166^{*}$} \\
\hline & High school & 4 & 10.0 & 0 & 0 & 4 & 5.0 & \\
\hline \multirow[t]{4}{*}{ Marital status } & Married & 29 & 72.5 & 30 & 75.0 & 59 & 73.8 & \multirow{4}{*}{0.797} \\
\hline & Separated & 3 & 7.5 & 3 & 7.5 & 6 & 7.5 & \\
\hline & Single & 7 & 17.5 & 7 & 17.5 & 14 & 17.5 & \\
\hline & Widow & 1 & 2.5 & 0 & 0 & 1 & 1.3 & \\
\hline
\end{tabular}

Chi-square test; *Fisher's exact test. 
Table 2. Percentages observed in the instrument categories in each group and association test result.

\begin{tabular}{|c|c|c|c|c|c|c|c|c|}
\hline \multirow[b]{3}{*}{ Instrument } & \multirow[b]{3}{*}{ Category } & \multicolumn{4}{|c|}{ Group } & & & \multirow[b]{3}{*}{$\mathrm{p}$} \\
\hline & & \multicolumn{2}{|c|}{ Study } & \multicolumn{2}{|c|}{ Control } & \multicolumn{2}{|c|}{ Total } & \\
\hline & & $\mathrm{n}$ & $\%$ & $\mathrm{n}$ & $\%$ & $\mathrm{n}$ & $\%$ & \\
\hline \multirow[t]{4}{*}{ BAI } & Minimum & 9 & 22.5 & 19 & 47.5 & 28 & 35.0 & \\
\hline & Slight & 14 & 35.0 & 6 & 15.0 & 20 & 25.0 & \\
\hline & Moderate & 9 & 22.5 & 11 & 27.5 & 20 & 25.0 & 0.040 \\
\hline & Serious & 8 & 20.0 & 4 & 10.0 & 12 & 15.0 & \\
\hline \multirow[t]{4}{*}{ HAM-D } & No symptoms & 7 & 17.5 & 15 & 37.5 & 22 & 27.5 & \\
\hline & Slight & 16 & 40.0 & 13 & 32.5 & 29 & 36.3 & \\
\hline & Moderate & 8 & 20.0 & 7 & 17.5 & 15 & 18.8 & 0.219 \\
\hline & Serious & 9 & 22.5 & 5 & 12.5 & 14 & 17.5 & \\
\hline \multirow[t]{2}{*}{ PSQI } & Good sleeper & 6 & 15.0 & 14 & 35.0 & 20 & 25.0 & \\
\hline & Bad sleeper & 34 & 85.0 & 26 & 65.0 & 60 & 75.0 & 0.039 \\
\hline
\end{tabular}

Chi-square test.

Table 3. Sleep pattern and quality.

\begin{tabular}{|c|c|c|c|c|c|c|c|c|}
\hline \multirow[b]{3}{*}{ Variable } & \multirow[b]{3}{*}{ Category } & \multicolumn{4}{|c|}{ Group } & & & \multirow[b]{3}{*}{$\mathrm{p}$} \\
\hline & & \multicolumn{2}{|c|}{ Study } & \multicolumn{2}{|c|}{ Control } & \multicolumn{2}{|c|}{ Total } & \\
\hline & & $\mathrm{n}$ & $\%$ & $\mathrm{n}$ & $\%$ & $\mathrm{n}$ & $\%$ & \\
\hline Sleep disturbances & $\begin{array}{l}\text { No time } \\
\text { Less than once/ without } \\
\text { Once/twice/without } \\
\text { Three times/without }\end{array}$ & $\begin{array}{c}1 \\
8 \\
25 \\
6\end{array}$ & $\begin{array}{c}2.5 \\
20.0 \\
62.5 \\
15.0\end{array}$ & $\begin{array}{c}1 \\
9 \\
26 \\
4\end{array}$ & $\begin{array}{c}2.5 \\
22.5 \\
65.0 \\
10.0\end{array}$ & $\begin{array}{c}2 \\
17 \\
51 \\
10\end{array}$ & $\begin{array}{c}2.5 \\
21.3 \\
63.8 \\
12.5\end{array}$ & $0.923^{*}$ \\
\hline Sleep latency & $\begin{array}{l}\leq \text { To } 15 \text { minutes } \\
16 \text { To } 30 \text { minutes } \\
31 \text { To } 61 \text { minutes } \\
>60 \text { Minutes }\end{array}$ & $\begin{array}{c}5 \\
10 \\
7 \\
18\end{array}$ & $\begin{array}{l}12.5 \\
25.0 \\
17.5 \\
45.0\end{array}$ & $\begin{array}{l}15 \\
8 \\
8 \\
9\end{array}$ & $\begin{array}{l}37.5 \\
20.0 \\
20.0 \\
22.5\end{array}$ & $\begin{array}{l}20 \\
18 \\
15 \\
27\end{array}$ & $\begin{array}{l}25.0 \\
22.5 \\
18.8 \\
33.8\end{array}$ & 0.040 \\
\hline Sleep effectiveness & $\begin{array}{l}>85 \% \\
75 \text { To } 84 \% \\
65 \text { To } 74 \% \\
<65 \%\end{array}$ & $\begin{array}{c}22 \\
7 \\
2 \\
9\end{array}$ & $\begin{array}{c}55.0 \\
17.5 \\
5.0 \\
22.5\end{array}$ & $\begin{array}{c}28 \\
3 \\
4 \\
5\end{array}$ & $\begin{array}{c}70.0 \\
7.5 \\
10.0 \\
12.5\end{array}$ & $\begin{array}{c}50 \\
10 \\
6 \\
14\end{array}$ & $\begin{array}{c}62.5 \\
12.5 \\
7.5 \\
17.5\end{array}$ & \\
\hline Sleep duration & $\begin{array}{l}>7 \text { Hours } \\
6 \text { To } 7 \text { hours } \\
5 \text { To } 6 \text { hours } \\
<5 \text { Hours }\end{array}$ & $\begin{array}{c}16 \\
10 \\
4 \\
10\end{array}$ & $\begin{array}{l}40.0 \\
25.0 \\
10.0 \\
25.0\end{array}$ & $\begin{array}{c}18 \\
10 \\
8 \\
4\end{array}$ & $\begin{array}{l}45.0 \\
25.0 \\
20.0 \\
10.0\end{array}$ & $\begin{array}{l}34 \\
20 \\
12 \\
14\end{array}$ & $\begin{array}{l}42.5 \\
25.0 \\
15.0 \\
17.5\end{array}$ & 0.259 \\
\hline Use of medication to sleep & $\begin{array}{l}\text { No time } \\
\text { Less than once/ without } \\
\text { Once/twice/without } \\
\text { Three times/without }\end{array}$ & $\begin{array}{c}22 \\
2 \\
1 \\
15\end{array}$ & $\begin{array}{c}55.0 \\
5.0 \\
2.5 \\
37.5\end{array}$ & $\begin{array}{c}34 \\
0 \\
0 \\
6\end{array}$ & $\begin{array}{c}85.0 \\
0.0 \\
0.0 \\
15.0\end{array}$ & $\begin{array}{c}56 \\
2 \\
1 \\
21\end{array}$ & $\begin{array}{c}70.0 \\
2.5 \\
1.3 \\
26.3\end{array}$ & $0.013^{*}$ \\
\hline Daily sleepiness & $\begin{array}{l}\text { No time } \\
\text { Small } \\
\text { Moderate } \\
\text { A lot }\end{array}$ & $\begin{array}{c}5 \\
6 \\
19 \\
10\end{array}$ & $\begin{array}{l}12.5 \\
15.0 \\
47.5 \\
25.0\end{array}$ & $\begin{array}{c}16 \\
8 \\
13 \\
3\end{array}$ & $\begin{array}{c}40.0 \\
20.0 \\
32.5 \\
7.5\end{array}$ & $\begin{array}{l}21 \\
14 \\
32 \\
13\end{array}$ & $\begin{array}{l}26.3 \\
17.5 \\
40.0 \\
16.3\end{array}$ & 0.012 \\
\hline Subjective quality of sleep & $\begin{array}{l}\text { Very good } \\
\text { Good } \\
\text { Bad } \\
\text { Very bad }\end{array}$ & $\begin{array}{c}22 \\
2 \\
1 \\
15\end{array}$ & $\begin{array}{c}55.0 \\
5.0 \\
2.5 \\
37.5\end{array}$ & $\begin{array}{l}34 \\
0 \\
0 \\
6\end{array}$ & $\begin{array}{c}85.0 \\
0.0 \\
0.0 \\
15.0\end{array}$ & $\begin{array}{c}56 \\
2 \\
1 \\
21\end{array}$ & $\begin{array}{c}70.0 \\
2.5 \\
1.3 \\
26.3\end{array}$ & $0.013^{*}$ \\
\hline
\end{tabular}

*Result of the reason test of verisimilitude.

$(\mathrm{p}<0.001)$. There were not expressive differences in relation to the level of school and to the social status between the study and the control groups. In the study group, 90\% attended the Elementary School and 72.5\% were married, while in the control-group, all of them (100\%) were attending Elementary School and 75\% were married. As for the age, the groups showed themselves statistically homogeneous. The study-group's and the control-group's aver- 
Table 4. Description of the brief-WHOQOL results and comparison between the groups.

\begin{tabular}{|c|c|c|c|c|c|c|c|c|}
\hline \multirow[b]{2}{*}{ Domain } & \multirow[b]{2}{*}{ Group } & \multirow[b]{2}{*}{ Average } & \multirow[b]{2}{*}{ DP } & \multicolumn{3}{|c|}{ Percentile } & \multirow[b]{2}{*}{$\mathrm{N}$} & \multirow[b]{2}{*}{$\mathrm{p}$} \\
\hline & & & & $1^{\text {st }}$ Quartile & Median & $3^{\text {rd }}$ Quartile & & \\
\hline \multirow[t]{2}{*}{ Physical } & Study & 0.65 & 0.21 & 0.46 & 0.66 & 0.82 & 40 & 0.075 \\
\hline & Control & 0.72 & 0.26 & 0.62 & 0.75 & 0.96 & 40 & \\
\hline \multirow[t]{2}{*}{ Psychic } & Study & 0.63 & 0.21 & 0.43 & 0.65 & 0.78 & 40 & 0.134 \\
\hline & Control & 0.68 & 0.27 & 0.47 & 0.77 & 0.92 & 40 & \\
\hline \multirow[t]{2}{*}{ Social relationships } & Study & 0.63 & 0.28 & 0.35 & 0.67 & 0.83 & 40 & 0.034 \\
\hline & Control & 0.75 & 0.29 & 0.52 & 0.83 & 1.00 & 40 & \\
\hline \multirow[t]{2}{*}{ Environment } & Study & 0.50 & 0.21 & 0.29 & 0.53 & 0.69 & 40 & 0.214 \\
\hline & Control & 0.56 & 0.19 & 0.38 & 0.59 & 0.72 & 40 & \\
\hline
\end{tabular}

age age was $37(\mathrm{DP}=10.4)$, with no difference between the ages of both groups $(\mathrm{p}=0.734)$.

The obtained data, through the HAM-D, showed higher values in the depressive symptoms for the studygroup ( $\mathrm{p}=0.023$ ), while the BAI's results did not show significant differences between both groups $(\mathrm{p}=0.081)$.

The study-group showed higher commitment in the quality of the sleep $(\mathrm{p}=0.002)$.

In Table 2, we may observe that the percentage of subjects from the study-group with minimal anxiety symptoms was lower than the one in the control-group, and that the relationship was inverted in the slight anxiety symptoms $(\mathrm{p}=0.040)$.

The percentage of bad sleepers was statistically higher among the subjects from the study-group. The PSQI results showed $85 \%$ of bad sleepers in the study-group and $65 \%$ in the control-group.

As to sleep pattern (Table 3), the subjects in the studygroup showed a higher percentage of elevated latency of sleep $(\mathrm{p}=0.040)$, used more medication to sleep $(\mathrm{p}=0.013)$, related higher daily sleepiness $(\mathrm{p}=0.013)$ when compared to the subjects in the control-group.

Concerning the perception of the quality of life (Table 4), we observed that, in the social relationship's domain, scores were statistically higher in subjects from the control-group ( $\mathrm{p}=0.034)$. This domain involves the personal relationships, the social support and the sexual life.

There was not correlation between the harvest's time and the results in the used instruments. Anxiety symptoms, depression symptoms and quality of the sleep were inversely related in the domains of the WHOQOL-bref, being more emphasized in the harvesters. The larger the scores in the anxiety symptom (BAI), depression symptom (HAM-D) and sleep (PSQI) scales, the smaller were the values in the WHOQOL-bref domains.

\section{DISCUSSION}

In this study, greater number of females in the labor per harvest and in the control-group the predominance of males were observed, showing the larger part of females in the work market in labor activities with shortterm contract, by their own or temporary ${ }^{11}$. In Castillo and Cassilas's ${ }^{12}$ study, the males' participation was superior to the females', different from our study in which we observed the homogeneous participation of males and females in the coffee harvest, where most of the females work as harvesters. Concerning the greater participation of females in the harvesters group, we may suppose that the worsening in the sleep disorders and the greater use of medicines to sleep may be related to hormonal impairment and to the easiness of searching for medical aid as observed in the Alcântara et al. ${ }^{13}$ study.

The presence of depression signs and symptoms was significant in both groups, being important for the evaluation of the quality of life $\mathrm{e}^{14}$, quality of the sleep ${ }^{15}$. Harvesters and fixed laborers may be liable to stresses and insecurities, as observed in other studies ${ }^{3,4}$. The rural labor is stressful for suffering influences from several factors like the coffee economy, the exportation, the availability of hand labor, the climatic changes and others.

In this study, higher punctuations in the study-group in what relates to insomnia and to the use of medication were observed, showing worse quality of the sleep. Results obtained from the anxiety and depression signs and symptoms scales suggest that it may occur sleep interference in the unchaining of depression and anxiety signals, as already observed in previous studies ${ }^{3,15}$. According to the results, the patients with stressful and precarious labors show a worse quality of sleep and more anxiety and depression signs and symptoms.

We observed, in this study, that there was a good perception of the QL among the subjects, being better in those who have fixed labor. The most compromised domain was the one of social relationships, what might be due to characteristics of life isolation in the countryside or even to the compromising of the mental health.

In conclusion, the study-group, there was impairment in the quality of the sleep, the occurrence of initial in- 
somnia with the use of medication to sleep and excessive daytime sleepiness; the depression and anxiety signs and symptoms appeared both in the study and control groups; in the quality of life evaluation we observed a loss in the social area among the patients in the study-group.

\section{REFERENCES}

1. Albarracin G, Rovira J, Carreras L, Rejas J. Aspectos económicos y epidemiológicos de los trastornos de ansiedad generalizada: una revisión de la literatura. Actas Esp Psiquiatr 2008;36:165-176.

2. Silva FPP. Burnout: um desafio à saúde do trabalhador. Psi Rev Psic Soc Inst 2000; 1. Disponível em: http://2.uel.br./ccb/psicologia/revista/textov2n15.htm.

3. Almondes KM, Araújo JF. Padrão do ciclo do sono-vigília e sua relação com a ansiedade em estudantes universitários. Estud Psicol 2003;8:37-43.

4. Vedolin G. Participação do estresse e ansiedade na alteração do limiar de dor à pressão (LPD) em pacientes com DTM miogênica em estudo comparativo [Dissertação]. Faculdade de Odontologia de Bauru, Universidade de São Paulo; São Paulo, 2006

5. Brucki SMD, Nitrini R, Caramelli P, Bertolucci PHF, Okamoto IHO. Sugestões para o uso do mini-exame do estado mental no Brasil. Arq Neuropsiquiatr 2003;61:777-781.
6. Buysse DJ, Reynolds CF, Monk TH, Berman SR, Kupfer DJ. The Pittsburgh Sleep Quality Index: a new instrument for psychiatric practice and research. Psychiatry Rev 1989;28:193-213.

7. Cunha JA. Manual da versão em português das Escalas Beck. São Paulo: Casa do Psicólogo, 2001.

8. Hamilton M. A rating scale for depression. J Neurol Psychiatry 1960;23:56-62

9. Fleck MPA, Louzada S, Xavier M, et al. Aplicação da versão em português do instrumento abreviado de avaliação de qualidade de vida "WHOQOL-bref". Rev Saúde Pública 2000;34:178-183.

10. Agresti A. Categorical data analysis. New York: Wiley, 1990.

11. Kovács I. Emprego flexível em Portugal. Sociologias 2004;12:32-67.

12. Castillo M, Cassilas R. Characteristics of Guatemalan migration of the Soconusco region in the State of Chiapas. Estud Demogr Urbanos Col Mex 1988;3:537-562.

13. Alcântara C, Reimão R, Rossini S, et al. Distúrbios do sono na mulher. In: Reimão R (Ed). Sono: atualidades. São Paulo: Associação Paulista de Medicina 2006:137-138.

14. Fernandez Fernández C, Garcia JC, Martinez P, González M, Barrondo S, García JB. La depresión en el anciano en una zona rural y su interacción con otros factores. Actas Esp Psiquiatr 2006:34:355-361.

15. Chellappa SL, Araújo JF. Qualidade subjetiva do sono em pacientes com transtorno depressivo. Est Psicol 2007;12:269-274. 